https://doi.org/10.1590/198053146560

\title{
INTERVENTION ON COUNTING PRINCIPLES: PROGRAM DEVELOPMENT AND INITIAL APPLICATION'
}

\author{
Évelin Fulginiti de Assis' \\ Luciana Vellinho Corso" \\ TRANSLATED BY Cristina Saez ${ }^{\prime \prime \prime}$
}

\begin{abstract}
This article discusses the construction of an intervention program on counting principles for first grade children, as well as the pilot study that put it into practice to evaluate its applicability (quality of proposals, duration and children engagement) and dynamics (contextualization, previous motivation, activity and systematization). Initial application was performed with ten children from a state school located in Porto Alegre (RS). A field diary was the instrument used for recording the sessions progress. The results showed a clear need for adjustments in the intervention (dynamics reorganization and selection of tasks), which were then made aimed at improving the program, enabling its future application in an experimental study.
\end{abstract}

\section{NUMERICAL CONCEPT • LEARNING • MATHEMATICS TEACHING}

\section{INTERVENÇÃO EM PRINCÍPIOS DE CONTAGEM: DESENVOLVIMENTO DO PROGRAMA E APLICAÇÃO INICIAL}

\section{Resumo}

Este artigo apresenta a construção de um programa de intervenção em princípios de contagem para crianças de $1^{\circ}$ ano do ensino fundamental, bem como o estudo-piloto que o colocou em prática para avaliar sua aplicabilidade (adequação das propostas, tempo de duração das mesmas e engajamento das crianças) e dinâmica (contextualização, motivação prévia, atividade e sistematização). A aplicação inicial foi realizada com dez crianças de uma escola estadual localizada em Porto Alegre-RS. O diário de campo foi o instrumento para registro do andamento das sessões. Como resultado, evidenciou-se a necessidade de ajustes na intervenção (reorganização da dinâmica e seleção de tarefas), os quais foram feitos de modo a promover a melhoria do programa, possibilitando sua futura aplicação em formato de estudo experimental.

\section{CONCEITO NUMÉRICO • APRENDIZAGEM • ENSINO DE MATEMÁTICA}

\footnotetext{
1 This study was financed in part by the Coordenação de Aperfeiçoamento de Pessoal de Nível Superior - Brazil (CAPES) Finance Code 001

I Universidade Federal do Rio Grande do Sul (UFRGS), Porto Alegre (RS), Brazil; http://orcid.org/0000-0002-8542-0607; evelin_assis@hotmail.com

II Universidade Federal do Rio Grande do Sul (UFRGS), Porto Alegre (RS), Brazil; http://orcid.org/0000-0001-6384-3994; luciana.corso@ufrgs.br

III Tikinet; traducao@tikinet.com.br
} 


\section{INTERVENTION SUR LES PRINCIPES DE COMPTAGE : DÉVELOPPEMENT DE PROGRAMME ET APPLICATION INITIALE Résumé}

Cet article présente la construction d'un programme d'intervention sur les principes de comptage auprès d'enfants de première année d'école primaire aussi bien que l'étude pilote qui l'a mis en oeuvre afin d'évaluer son applicabilité (adéquation et durée des propositions, engagement des enfants) et la dynamique (contextualisation, motivation antérieure, activité et systématisation). L'application initiale a été mise en place avec dix enfants dans une école publique de la ville de Porto Alegre-RS. Le journal de bord a été choisi comme instrument pour enregistrer la progression des séances. Les résultats ont indiqué la nécessité de procéder à des ajustements de l'intervention (réorganisation de la dynamique et sélection des tâches) qui ont été réalisées de façon à avancer dans l'amélioration du programme, rendant possible son application future en tant qu'étude expérimentale.

\section{CONCEPT NUMÉRIQUE • L’APPRENTISSAGE • ENSEIGNEMENT DES MATHÉMATIQUES}

\section{INTERVENCIÓN SOBRE PRINCIPIOS DE CONTEO: DESARROLLO DEL PROGRAMA Y APLICACIÓN INICIAL}

\section{Resumen}

Este documento presenta la construcción de un programa de intervención sobre principios de conteo para niños de primer grado de enseñanza fundamental, así como el estudio piloto que lo puso en práctica para evaluar su aplicabilidad (adecuación de las propuestas, tiempo de duración de éstas e implicación de los niños) y dinámica (contextualización, motivación previa, actividad y sistematización). La aplicación inicial se realizó con diez niños de una escuela estatal ubicada en Porto Alegre-RS. El diario de campo fue el instrumento para registrar el progreso de las sesiones. Como resultado, se evidenció la necesidad de ajustes en la intervención (reorganización de la dinámica y selección de tareas), que se realizaron para promover la mejora del programa, permitiendo su aplicación futura en formato de estudio experimental.

CONCEPTO NUMÉRICO • APRENDIZAJE • ENSEÑANZA DE MATEMÁTICA 
ATHEMATICS IS A COMPLEX AREA OF STUDY WITH NUMEROUS COMPLEMENTARY factors involved in its construction. Therefore, learning mathematics offers difficulties for many students, and its teaching faces a series of challenges (CORSO; ASSIS, 2017). As discussed by Corso (2013, p. 65), understanding development and learning as complex phenomena, which start from the interaction of many factors, enables the contextualization and problematization of the nature of learning difficulties, which are also complex.

Many authors have devoted themselves to the study of how children learn mathematics, emphasizing the key aspects involved in such a process. In this sense, researchers have conducted predictive studies (JORDAN; GLUTTING; RAMINENI, 2010; PASSOLUNGHI; VERCELLONI; SCHADEE, 2007; STOCK; DESOETE; ROEYERS, 2009) to understand the knowledge at the base of mathematical construction; studies of academic and cognitive profile (CIRINO et al., 2013; NELSON; POWELL, 2018) to analyze the characteristics of the group of students with and without learning difficulties in mathematics; and intervention studies (DYSON; JORDAN; GLUTTING, 2011; FUCHS et al., 2010) to put in place practices to help these children improve their performance in the area.

To better understand these issues, the concepts of number sense and counting principles will be discussed from now on, complementing them with some studies to elucidate their role in mathematical learning. 


\section{NUMBER SENSE}

The field of number sense studies is broad and controversial. Several researchers have devoted themselves to studying its origin and definition (BARBOSA, 2007; BERCH, 2005; CORSO; DORNELES, 2010; DEHAENE, 1997; NUNES; BRYANT, 1997; SPINILLO, 2014). Regarding origin, one can identify two currents that, although viewed as opposites, are currently recognized as complementary (SPINILLO, 2014): the innatist current and the constructivist current. Spinillo (2014) explains that, although there is, in fact, a biological apparatus that allows attention to numerosities, as demonstrated by innatist studies (ANTELL; KEATING, 1983; DEHAENE, 1997; STARKEY; COOPER, 1980), social experiences must happen to build mathematical knowledge.

Some of these experiences happen in children's daily life, such as organizing toys or sharing candies among people, putting into practice mathematical knowledge and skills. These are part of the concept called number sense (BERCH, 2005; CORSO; DORNELES, 2010), also called numerical sense (BARBOSA, 2007; SPINILLO, 2014) and/or numeralization (NUNES; BRYANT, 1997).

Number sense encompasses various aspects and skills, generally referring to children's flexibility and ease with numbers, as well as their understanding of their meaning and related ideas (CORSO; DORNELES, 2010, p. 299). According to Corso and Dorneles (2010, p. 300, own translation), number sense is

\footnotetext{
[...] a general construct that encompasses a very broad set of concepts, which the student gradually learns from their interactions with the social environment. It is a way of interacting with numbers, with their various uses and interpretations, enabling the individual to deal with everyday situations that include quantification and the development of efficient strategies (including calculation and estimation) to deal with numerical problems. ${ }^{2}$
}

Among this knowledge, counting principles play a prominent role and are discussed below.

\section{COUNTING PRINCIPLES}

Counting is an extremely important knowledge that starts to be developed informally by children through everyday experiences. Its relevance is highlighted by several authors, and Dorneles (2004, p. 2-3, own translation) nicely summarizes the ideas by stating that

2 In the original: "um constructo geral, que engloba um conjunto de conceitos bastante amplo, o qual o aluno aprende gradativamente a partir de suas interações com o meio social. É uma forma de interagir com os números, com seus vários usos e interpretações, possibilitando ao indivíduo lidar com situações diárias que incluem quantificações e o desenvolvimento de estratégias eficientes (incluindo cálculo e estimativa) para lidar com problemas numéricos." 


\begin{abstract}
[...] counting has been considered an important cognitive tool not only for the understanding of later contents but also for the development of more elaborate and meaningful mathematization skills. ${ }^{3}$
\end{abstract}

Knowing their relevant role, one must pay attention to the development of this learning. When children learn to count, they must put into practice some principles to guide this action, as well as understand what counting is for and how to do it correctly (NUNES; BRYANT, 1997).

Some of the first authors to devote themselves to understanding counting were Gelman and Gallistel (1978), who established five principles that would define and constitute the counting process. The first principle, one-to-one correspondence, concerns the fact that, when marking items in a set, each will be marked distinctly and only once. The second principle refers to the stable order, which means the labels used to match items in the set will always be arranged in the same way, in a stable (repeatable) order. The third principle, cardinality, means that the last label in the array of items counted in the set represents the property of the set as a whole, i.e., it represents the total of items in the set. The fourth principle is abstraction, which states that the previous principles can be applied to any set. The fifth and final principle, order irrelevance, implies that the order of items enumeration does not matter, because the same cardinal number will be found as a result of the set regardless of the counting order, provided that the other principles are respected.

To summarize, the first three are classified as "how to count" principles. The fourth defines what is "countable" and the fifth consists of a synthesis of the application of the previous ones. The five form the basis of the child's later numerical construction (DORNELES, 2004). Considering what has been exposed so far, one can analyze some studies in the area and realize, in practice, the role of number sense and counting principles in children's mathematical learning.

\title{
FIELD OF RESEARCH
}

Researchers of learning and learning disabilities in mathematics count on numerous aspects to investigate. Among them, some studies involving predictors of learning, profile of students with and without difficulties in mathematics (DM) and intervention studies will be highlighted.

Studies on the predictive factors of mathematical learning have shown that: counting tests, involving the assessment of counting principles, were one of the most efficient predictors of mathematical ability in a sample of children assessed at the beginning and end of first grade (elementary school)

3 In the original: "a contagem tem sido considerada como uma ferramenta cognitiva importante não só para a compreensão de conteúdos posteriores como também para o desenvolvimento de habilidades de matematização mais elaboradas e significativas." 
(PASSOLUNGHI; VERCELLONI; SCHADEE, 2007); children assessed to have good counting skills in the final year of preschool also showed good performance in arithmetic skills later in the first grade (STOCK; DESOETE; ROEYERS, 2009); and the number sense of children assessed in the 1st year of elementary school proved to be a strong predictor of mathematical results in the 3rd grade (JORDAN; GLUTTING; RAMINENI, 2010).

One can conclude that number sense and counting play a fundamental role in mathematical learning. Considering this, studies were also developed investigating the profile of students with and without difficulties in this area, in order to analyze which skills would be preserved and/or impaired. The results show that students of about seven years of age with math difficulties performed worse than students with reading difficulties, showing poor performance in estimation and retrieving basic facts from memory (CIRINO et al., 2013). A systematic review of 35 studies showed that struggling students, most of them in the early years of elementary school, had consistent deficits in counting, calculating, using recovery strategies, comparing fractions, and estimation and solving problems (NELSON; POWELL, 2018).

Taking into account the predictive factors oflearning and the characteristics of groups of children with and without learning disabilities in mathematics, one can also think of strategies and interventions aimed at assisting them in the learning process, both in terms of prevention and treatment. Interventions have shown that, among their results, 3rd grade children who received teaching on numerical matching and counting skills were better than those who did not (FUCHS et al., 2010). Early childhood students who participated in a number sense intervention also showed more progress than students who did not participate in the intervention, pointing to the positive effect of this practice (DYSON; JORDAN; GLUTTING, 2011).

The need for specific interventions for students with or at risk of developing learning disabilities in mathematics is highlighted by several authors. Nelson and Powell (2018) conclude from a systematic review of longitudinal studies on math difficulties that students with DM perform worse than their peers without difficulties throughout all school years and in various mathematical skills. The likelihood of continuing with such performance during schooling is high, as is the impossibility of reaching their typically-developing peers: without specific interventions and early identification of DM, children as young as those in kindergarten may be at risk of developing problems in elementary school and even in adulthood (NELSON; POWELL, 2018).

Considering the studies presented so far, one must draw attention to the intervention studies already mentioned. Although they have addressed number sense and its main components, there are very few studies involving specific counting interventions, which reveals the need for further research in this area. Stock, Desoete and Roeyers (2009) point out that more than half of the children in the studied sample $(\mathrm{N}=423)$ did not master some counting principles at the 
end of kindergarten, emphasizing that these are good predictors of mathematical performance and, thus, should receive more attention from teachers.

Taking these aspects into account, this study aimed to develop an intervention program on counting principles and to apply it as a pilot study to a 1st grade class of elementary school. Program application aimed to evaluate the adequacy of the chosen tasks, analyze the time devoted to each one, and verify the children's engagement in the proposals, so that, if necessary, adjustments were made prior to the experimental study.

\section{CONSTRUCTION OF THE INTERVENTION PROGRAM ON COUNTING PRINCIPLES}

To develop this intervention program, one had to search the existing literature to identify important and effective factors that positively contributed to the intervention.

Mononen et al. (2014), in a review of initial numeralization interventions for children at risk of developing math difficulties, aged 4 to 7 years old, examined 19 studies published between 2000 and 2012. Overall, they have shown that early numeralization interventions can effectively improve the numerical skills of young children at risk of developing DM. In most studies, children in the intervention group were better than those in the control group. Small group sessions were the main technique, demonstrating the possibility of working more closely with children and thus paying more attention to their needs.

Dennis et al. (2016), in a meta-analysis of 25 empirical studies on teaching children aged 5-10 years old with math difficulties, published from 2000 to 2014, showed that interventions with an instructional design of task sequencing (from easy to difficult) and the teaching of explicit concepts and procedures were beneficial for students with DM. In addition, results showed the intervention performed in small groups was also positive.

This idea is also emphasized by other authors, such as Clarke et al. (2015), by presenting valid principles for interventions. The authors highlight three important aspects: engagement of students' prior knowledge, promotion of teaching interactions, and mathematical verbalizations.

The first concerns the fact that teachers working with struggling students initially need to explicitly teach some skills that are a prerequisite for learning more complex content. This support for students' prior knowledge can be accomplished through warm-up exercises at the beginning of each session, allowing students to make connections between previously learned content and new content (CLARKE et al., 2015).

The second aspect, about interactions in teaching, involves the idea of gradually making the student responsible for their learning. To know the amount of teaching to be devoted to students, teachers must consider their prior knowledge and the knowledge required to complete the tasks alone and successfully. Finally, mathematical verbalizations play an important role as they 
give students the opportunity to talk about mathematics through their specific language and to think mathematically (CLARKE et al., 2015). These principles presented by Clarke et al. (2015) helped to organize the intervention program of this study, along with the ideas expounded by Fuchs and Fuchs (2001) about the different levels of intervention and the underlying principles of each.

The authors draw attention to primary, secondary and tertiary education levels. At the primary level, where teaching is provided to all students, teachers can use: fast pace, varied activities, and engagement; challenge performance standards; self-verbalization; visual and physical representations. At the secondary level: adaptations that are easy to adopt so that the primary school teacher can implement them in the classroom routine; adaptations cannot be a problem for children in focus; adaptations cannot be invasive to other children. At the tertiary level, teaching takes the form of an intensive and individual intervention: focus on the student as a unit for teaching and decision making; intensive teaching; contextualization and explicit teaching of basic skills (FUCHS; FUCHS, 2001).

Considering the principles exposed so far, one should clarify that the intervention developed in this study sought to incorporate them, in order to favor students' learning and enable their implementation by teachers in basic education classrooms.

In addition to providing a solid foundation for the program, based on the aforementioned aspects, the literature assisted in choosing and developing tasks for each intervention session. As the focus of this study are counting principles, the tasks applied in the intervention studies by Toll and Van Luit (2013), Ramani and Siegler (2008), Dyson, Jordan and Glutting (2011), Alves and Barbosa (2016), Lopes, Roos and Bathelt (2014), Praet and Desoete (2014), Dowker and Sigley (2010) and the PNAIC Playbook (BRASIL, 2014) contributed to the development of tasks of the Counting Principles intervention program described below.

\section{INTERVENTION PROGRAM ON COUNTING PRINCIPLES}

The developed intervention was organized to be applied twice a week for four weeks, totaling eight sessions. The duration of each session was idealized at approximately 45 minutes, considering the travel time of the children (five minutes to go to the intervention room, five to go back to the classroom), to be performed with small groups of up to ten students. Tasks designed for each session followed a fixed order: contextualization (five minutes), previous motivation (five minutes), activity (15 minutes) and systematization (ten minutes).

The contextualization, conceived according to the tertiary level of teaching principles expounded by Fuchs and Fuchs (2001), consisted of a brief moment, at the beginning of each intervention, in which the researcher sought to promote a discussion about the context of that meeting. Previous motivation was based on the ideas of Clarke et al. (2015): helping students make the connection between prior knowledge and the content to be learned. The activity took place only after contextualization and previous motivation, providing the opportunity to 
practice what was previously talked about. Following the guiding principles of Fuchs and Fuchs (2001), a variety of fast-paced activities were used, using physical and visual representations that challenged student performance standards. The systematization, the final moment of each session, aimed to synthesize the learning of the meeting, allowing the children to record or verbalize what was learned from the activity. At this moment, the idea of mathematical verbalization, proposed by Clarke et al. (2015), gained prominence.

\section{INITIAL APPLICATION - PILOT STUDY}

The pilot study aimed to implement the intervention program on counting principles, to analyze its applicability in terms of: quality of the proposals, through the observation of children's engagement in each task; duration of sessions and activities; functionality of the dynamics thought for each meeting (contextualization, previous motivation, activity and systematization). For this, the researcher kept a field diary in which she recorded a summary of each session as she was conducting the intervention. These records consisted of indications about the progress of sessions and tasks, as well as notes about the children's engagement and use of time in each meeting. This instrument enabled to conduct a documentary research, which, unlike the literature review, is characterized by the use of materials that have not yet received analytical treatment, as was the case of the role played by the field diary (GIL, 2009). This instrument enabled us to analyze the pilot study and, consequently, to make adjustments to the intervention program.

For such, a small 1st-grade class of a state school in Porto Alegre-RS, with ten students, participated in the study. The sample size corresponded exactly to the ideal number of participants provided for in the intervention design. The school received the Authorization Term and the responsible teacher received a Participation Term. All students in the class were allowed to participate in the study through the Informed Consent Form.

Because of the time available for the pilot study and the needs of the school, the eight planned sessions needed to be done differently: instead of twice a week for four weeks, they were longer (1h30min) and happened twice a week over two weeks. Due to the increased time available (from $45 \mathrm{~min}$ to $1 \mathrm{~h} 30 \mathrm{~min}$ ), two sessions per meeting were held, with the objective of maintaining the initial schedule (totaling eight sessions) and evaluating the effectiveness and duration of the proposals.

\section{INTERVENTION SESSIONS}

The following are the intervention sessions that, for better organization, are described separately. The explanation of each meeting begins with the presentation of the objective, followed by the theoretical background, context and details of activity development, along with comments highlighting how it was conducted. Then there is the table with information about the previous 
motivation, systematization and indications of changes in the intervention program from the field diary.

\section{1st session}

In this meeting, the objective was to work on the principles of stable order, one-to-one correspondence, and cardinality. The theoretical basis of the proposals was "to encourage students to speak, write and contextualize the number in their daily lives"4 (LOPES; ROOS; BATHELT, 2014, p. 33). In contextualization, the children were asked if they knew the reason for our meetings. We explained what would be done over the next few weeks, how we would work together. We clarified that, among everyone present, some knew some things and others not, explaining what we would learn together. After the initial motivation described in Chart 1 was performed. The kids liked this moment because they could stop to think of the places where numbers are seen. We started then the activity with magazine and newspaper reports, in which children were to locate and identify the numbers. They would be asked to cut and place them in a box, called the "number box" (Figure 1). Although it seems simple to do, it was complicated at the time to organize it that way.

\section{FIGURE 1}

PHOTOGRAPH OF "NUMBER BOX"

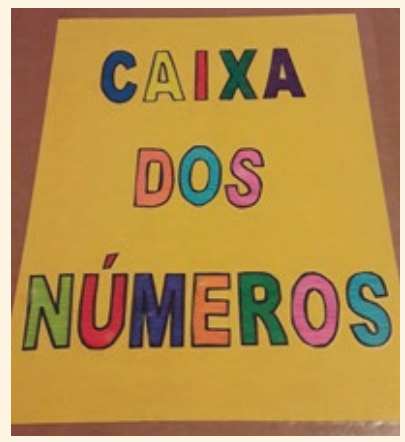

Source: Recorded by the authors (2017)

Then, the reports were placed directly in the box and the students were called one by one to pick one and return to the place. When asked what they noticed in the papers, everyone said there were numbers. After socializing the findings, the proposal was to sort the numbers found by pasting them onto a sheet (if repeated, they should be pasted below each other). After this ordination, according to the initial proposal, the children would be asked to count the numbers in the order, then to count the repeated ones and write down how many of each were found. However, as collective socialization was doing well, the initial idea was changed at the moment. Thus, one at a time, they said aloud 
the numbers on their sheets. Afterwards, a child ordering was done. Whoever had number 1 in his report would go to the front of the board. Together, we were calling the following numbers. We arrived at 9. With everyone standing, we count from the smallest to the largest. Then from largest to smallest. At the end of the activity, the systematization was made, detailed in Chart 1.

\section{CHART 1}

\section{MOMENTS OF THE 1ST SESSION OF INTERVENTION ON COUNTING PRINCIPLES}

\begin{tabular}{|l|l|}
\hline $\begin{array}{l}\text { Previous Motivation: Initial conversation with } \\
\text { children about numbers. Questions: Where do we } \\
\text { see numbers? What are they worth for? How can } \\
\text { we count them? Write down the ideas on a paper. }\end{array}$ & $\begin{array}{l}\text { Systematization: note how many numbers were } \\
\text { found and discuss what was possible to observe } \\
\text { during the activity. Question what the children } \\
\text { thought, if it was difficult or easy, if they noticed } \\
\text { something new, etc. All materials produced in the } \\
\text { sessions will be placed in the number box. }\end{array}$ \\
\hline $\begin{array}{l}\text { Suggestions for adjusting the intervention: } \\
\text { maintain the initial approach to the numbers, as } \\
\text { well as their contextualization through the reports; } \\
\text { maintain number ordering to work constant order } \\
\text { and one-to-one correspondence; remove the } \\
\text { cut and paste part; ask the children what would } \\
\text { happen if we counted the same number more than } \\
\text { once; do the systematization collectively. }\end{array}$ \\
\hline
\end{tabular}

Source: Authors' elaboration (2018).

\section{2nd session}

At this meeting, the principles sought were stable order, one-to-one correspondence, and order irrelevance. The authors who supported the elaboration and adaptation of the proposals were Alves and Barbosa (2016), Dowker and Sigley (2010) and Praet and Desoete (2014). Contextualization would consist of a brief conversation about the previous session and, from the box of numbers, the activity performed would be resumed. As this session, in the pilot study, was done shortly after the previous one (due to the school needs), this moment ended up happening after the systematization of the newspapers and magazines task. We questioned if it was possible to count the numbers only in line, from side to side: the class's initial answer was yes. Then the questioning followed, already putting into practice the initial motivation described in Chart 2. "What if I counted 1 here (touching a front student), then 2 here (student on the back), 3 there (on the side) ... Is it possible?". The answer was no, reinforcing the idea that one counts only one way, but one student said yes, we could count from anywhere. From this answer, the activity planned for the session - "cat bed" - was proposed. 


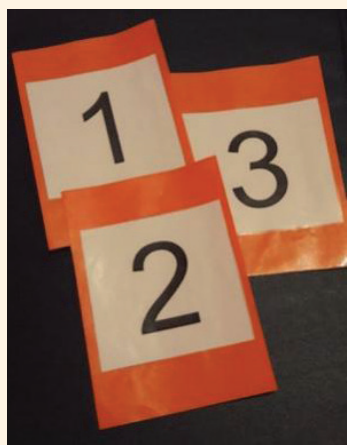

Source: Recorded by the authors (2017)

We made a circle on the floor and each child received a card with a number. Afterwards, the student with the number 1 received a string roll that was to be thrown to the next number and so on. The children were very surprised with the drawing that the string was making and, throughout the game, we were counting together. We made it from number 1 to 9 and then from 10 to 18 . At the end, all returned to their places and the systematization was performed, detailed in Chart 2.

\section{CHART 2}

MOMENTS OF THE 2ST SESSION OF INTERVENTION ON COUNTING PRINCIPLES

\begin{tabular}{l|l}
$\begin{array}{l}\text { Previous Motivation: Ask the children how have } \\
\text { we counted the numbers in the last session. } \\
\begin{array}{l}\text { Question whether there are other ways of } \\
\text { counting or if we can only count on the line from } \\
\text { side to side. After this conversation, challenge the } \\
\text { children to tell otherwise through play. }\end{array}\end{array}$ & $\begin{array}{l}\text { Systematization: write the numbers counted, } \\
\text { in the ways that were counted (ascending and } \\
\text { descending orders). If necessary, use the cards as } \\
\text { visual aid. }\end{array}$ \\
\hline
\end{tabular}

Suggestions for adjusting the intervention: keep the "cat bed", but think of a better way to perform it because it was confusing. If any activity must be removed from the intervention, this one is a possibility.

Source: Authors' elaboration (2018).

\section{3rd session}

In this session, the counting principles of stable order, one-to-one correspondence, order irrelevance, and cardinality were addressed. Studies by authors Dowker and Sigley (2010), Praet and Desoete (2014) and Lopes, Roos and Bathelt (2014) supported the proposals. As in the previous session, contextualization consisted of a brief conversation about the prior meeting. Prior motivation (Chart 3) helped at this moment, helping the children to remember the "cat bed" play and allowing one, from that, to ask the questions. Then, drawn figures were presented, such as a ladybug. 


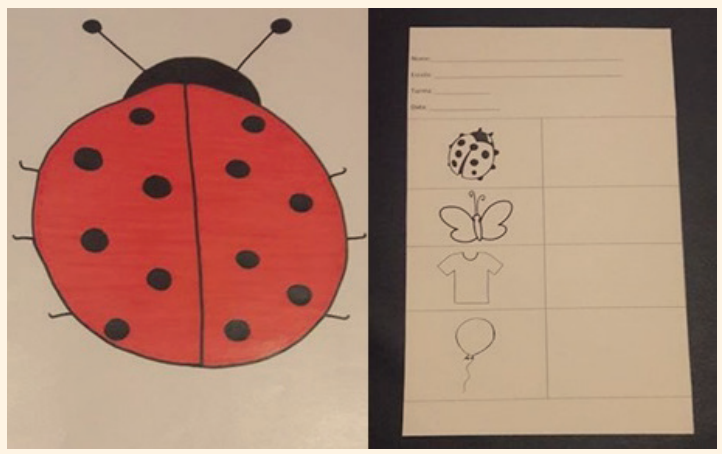

Source: Recorded by the authors (2017).

Each picture contained a certain number of balls, which should be counted by the children. Initially, they would be asked to count without the aid of material. The assumption is that difficulties would arise and, therefore, in a second moment caps would be distributed to aid in counting. At the time of performing the activity, we realized it needed to be better explained, perhaps even playing a round collectively, with the example of the intervener counting and erring and, later, relying on the support material. At the end of the task, the idealized systematization was performed, but it was evident the need to rethink it, due to the time and demand of writing the numbers of each figure.

\section{CHART 3}

MOMENTS OF THE 3ST SESSION OF INTERVENTION ON COUNTING PRINCIPLES

\begin{tabular}{|c|c|}
\hline $\begin{array}{l}\text { Previous motivation: remember the "cat bed" } \\
\text { game and ask what helped to count the numbers, } \\
\text { in order to highlight that the string went only once } \\
\text { for each number. Ask the children whether this } \\
\text { helped or made counting difficult and if it could } \\
\text { be done with string alone or if we would have } \\
\text { other ways to keep track of counting. }\end{array}$ & $\begin{array}{l}\text { Systematization: When all are done, we will talk } \\
\text { about the quantities found, in order to emphasize } \\
\text { the issue of cardinality. There will be an oral } \\
\text { round, which will ask how many balls were in each } \\
\text { picture. As children respond, they will be asked } \\
\text { how we can know this, with the aim of coming } \\
\text { to the conclusion, along with them, that the last } \\
\text { number counted corresponds to the total number } \\
\text { of balls used. }\end{array}$ \\
\hline
\end{tabular}

Suggestions for adjusting the intervention: maintain the activity of the figures; do the example first, collectively, and then distribute figures to each one; make files to help with counting; to emphasize further the question of the irrelevance of order and cardinality, showing that no matter which ball starts counting, the same number will always be found.

Source: Authors' elaboration (2018).

\section{4th session}

In this meeting, the principles of stable order, one-to-one correspondence, and cardinality were addressed. Activities were adapted from the work of Lopes, Roos and Bathelt (2014). Contextualization was performed as in the previous sessions, through a brief resumption, followed by the previous motivation described in Chart 4. The planned activity for this session was "the centipede": each child received small colored circles with written numbers. 
FIGURE 4

PHOTOGRAPH OF ACTIVITY "THE CENTIPEDE"

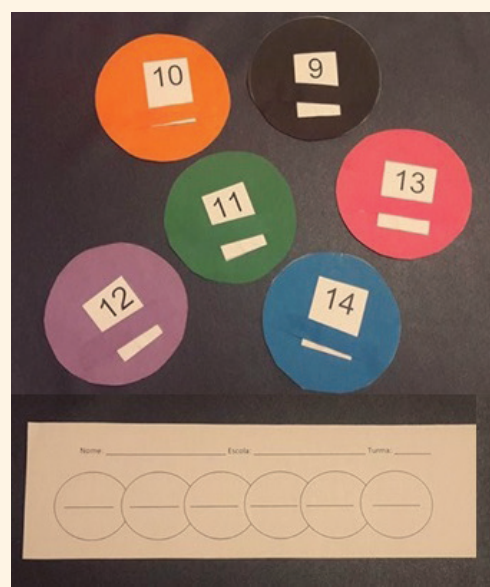

Source: Recorded by the authors (2017).

The proposal was for the children to sort the numbers in order to set up a centipede (some received numbers from 1-5, others from 5-10, etc.). After such assembly, the children socialized their strategies and organizations. The development of this activity was a little complicated due to the materials organization. We noticed it was important to leave the circles and numbers together from the outset before handing them over to the children. In addition, the need to shuffle them better and deliver more than one set to each child was highlighted. At the end of the task, systematization was performed as described in Chart 4, but did not appear to be as positive as the socialization of the strategies used by each child to organize the centipedes.

\section{CHART 4}

MOMENTS OF THE 4ST SESSION OF INTERVENTION ON COUNTING PRINCIPLES

\begin{tabular}{|c|c|}
\hline $\begin{array}{l}\text { Previous Motivation: according to recent } \\
\text { discussions in intervention sessions, children } \\
\text { will be asked about the order of counting. Some } \\
\text { questions will be asked to discuss with the } \\
\text { children: do we always need to count from } 1 \text { ? If } \\
\text { we have to sort some numbers and we do not } \\
\text { have a } 1 \text { between them, which one should we start } \\
\text { with? What if I don't have a } 2 \text { ? Should we always } \\
\text { arrange them in a straight line, or can we arrange } \\
\text { them as we please? }\end{array}$ & $\begin{array}{l}\text { Systematization: after the socialization of } \\
\text { centipedes, questions asked in the previous } \\
\text { motivation will be resumed. Each will receive a } \\
\text { sheet with a centipede and should type in the } \\
\text { numbers ordered, and then save it in the number } \\
\text { box. We will discuss if the answers were confirmed } \\
\text { or not, how it was for each one to assemble their } \\
\text { centipede, etc. }\end{array}$ \\
\hline
\end{tabular}

Suggestions for adjusting the intervention: better organize activity and time. Like "cat bed", this is an activity that can be removed from intervention if needed.

Source: Authors' elaboration (2018).

\section{5th session}

In this session, games were used to work on the principles of stable order, one-to-one correspondence, cardinality, order irrelevance and abstraction. Proposals were adapted from Ramani and Siegler (2008), Toll and Van Luit 
(2013) and the PNAIC playbook (BRASIL, 2014). Again, the session started with contextualization and moved on to the previous motivation (Chart 5). The activity of this meeting required the class to be organized into groups and each received a different game. Stick Grab: The group received a game of sticks and played as usual. Each stick was worth a point, which was noted by each child in the way they preferred. At the end of each round (there will be three), the points were counted and compared. Who had more points, won. Two hands: children received two trays with two drawn hands, Popsicle sticks and two dice. One child threw the dice and the number found was collected on Popsicle sticks. She handed the stick to her colleague and said they should be placed on the fingers of the board, indicating which finger the colleague should start putting them on. After the first round, the turn went to the other colleague, repeating each step again. Color Match: The group received a board in which the boxes contained no numbers, only colors. Each player received a pin and a piece of paper. The dice also had colors instead of numbers. Each player threw it and walked to the color drawn on the dice. In addition, the child noted on his piece of paper how many houses he walked. For example: the pin was in the yellow square and the dice indicated the blue square, so it had to walk through red and green, that is, two squares. Who reached the end first won the game.

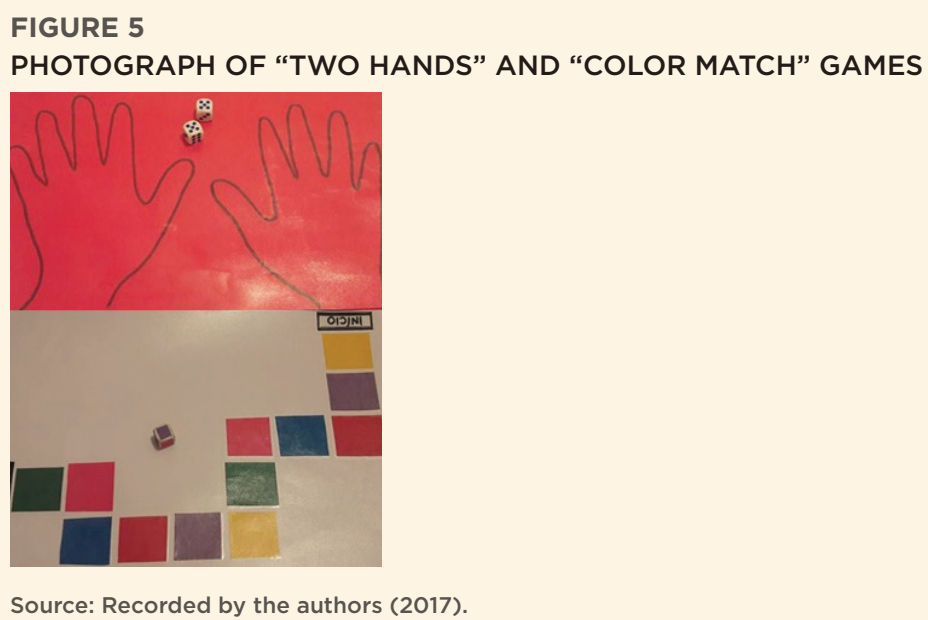

The progress of the games was a bit complicated, as everyone was very eager to play all, and time ended up being a problem. Annotation after the stick game was also more difficult, being indicated in the field diary records as a point to be rethought. Systematization was performed according to the description in Chart 5. 
Previous Motivation: Summarizing what has been discovered so far (that we always count the same way; we count only one number; no matter where we start counting because we will always follow the same order of numbers; the last spoken number corresponds to total number of objects counted, and that we count many different things and could count anything), the challenge of putting all this knowledge into practice through some games will be launched.

Suggestions for intervention adjustment: to analyze which games to maintain and rethink the systematization. The "color match" and "two hands" games seemed to be good tasks, while "stick grab" got a little confusing. If you need to remove some activity, the latter is an alternative.
Systematization: After each group plays each game at least once, everyone will be able of difficulty and/or ease, if they discovered something new, etc. to comment on what they think, the degree

\section{6th session}

At this meeting, all the principles of counting were pursued. The basis of the session corresponds to the idea of mathematical verbalization by Clarke et al. (2015). The session began with contextualization, followed by previous motivation. The proposed activity was bingo: each child received a bingo card containing numbers. Small cards containing some "riddles" were drawn, such as "I am the number that comes after 5 and before 7", "I am the number that comes after 10 and before 12 " and so on. Children who had the corresponding number on their card should mark it.

\section{FIGURE 6}

PHOTOGRAPH OF "BINGO" ACTIVITY

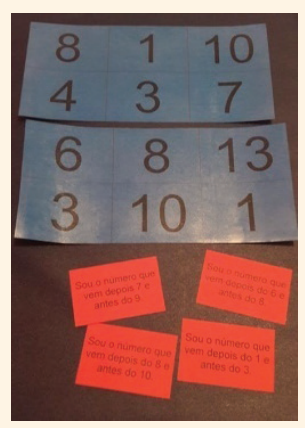

Source: Recorded by the authors (2017).

The game was won by the one who completed the card first. The progress of this task was very good, the students enjoyed and were engaged, demonstrating understanding of the riddles. The visual aid of the numbers written on the board was positive as it helped those students who were having trouble finding the answers. Systematization was performed as described in Table 6. 
Previous Motivation: Children will be asked if a number can be discovered by knowing only which ones come before and after it. Then, they will be challenged to play a number bingo.
Systematization: cards will be placed in the number box and the children will have to socialize as they did to find out which number the riddle's answer was, telling them if they counted, knew it already, etc.

Suggestions for intervention adjustment: keep bingo, review systematization (perhaps withdraw or perform it orally).

Source: Authors' elaboration (2018).

\section{7th session}

In this session, again, all counting principles have been worked. The proposed task was adapted from the work of Dyson, Jordan and Glutting (2011) and the PNAIC playbook (BRASIL, 2014). The meeting began with contextualization and previous motivation (Chart 7). The proposed activity was a game called "which one is missing?". Numbered cards were arranged on the floor of the room, the same shown in Figure 2, from 1 to 10 (after, from 1 to 20 or more, according to the difficulty degree of the group). The children had to count them and report whether they were all there or not, and were then asked to turn their backs while removing one or more numbers from the sequence. Turning the cards back on, the students identified the missing number and put it in the right place. The game worked very well and proved to have more possibilities such as, for example, for the students to pull out the numbers themselves. Systematization, described in Chart 7, was a little troubled, perhaps because many children participated at the same time.

\section{CHART 7}

\section{MOMENTS OF THE 7ST SESSION OF INTERVENTION ON COUNTING PRINCIPLES}

Previous Motivation: Students will be challenged to share what they already know about counting and ways of counting. Then, they will be asked:

If we are looking at an incomplete sequence of numbers, can we find out which number is missing?
Systematization: The children will receive sheets of paper, small cards with written numbers, and will be organized in pairs. Each must assemble a sequence of numbers, with some of them missing, and exchange with the colleague. That way, everyone can assemble and complete a sequence. Afterwards, the cards will be pasted on the sheets and all will go to the number box.

Suggestions for adjusting the intervention: better maintain and organize, especially the second part; consider keeping only the first step and performing it more often and calmly so that each student can play once; include, when organizing records, errors in number ordering, causing children to indicate whether the researcher is ordering correctly or not.

Source: Authors' elaboration (2018).

\section{8th session}

In this session, again, all counting principles have been addressed. Its theoretical basis was the study of Dyson, Jordan and Glutting (2011). The session began with contextualization, followed by previous motivation. In the activity 
called "number twister", colored circles with written numbers were stuck to the floor.

FIGURE 7

PHOTOGRAPH OF "NUMBER TWISTER" ACTIVITY

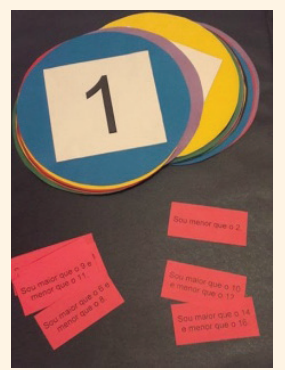

Source: Recorded by the authors (2017).

One student at a time spun the 'roulette' made up of envelopes. Inside each envelope was a "riddle" like those of bingo: "I'm the number that comes after 8 and before 10." The child stopped over the corresponding number. After everyone spun the roulette wheel and put themselves in their numbers, they organized to arrange them the way they wanted. After the initial ordination, the children were asked to order from highest to lowest. Finally, students were asked how many numbers they had in total. The systematization described in Chart 8 did not occur due to lack of time, as the activity took longer than expected.

\section{CHART 8}

MOMENTS OF THE $8^{\text {ST }}$ SESSION OF INTERVENTION ON COUNTING PRINCIPLES

\begin{tabular}{l|l} 
Previous Motivation: as this will be the last & Systematization: We will discuss how the sessions \\
session, students will be challenged to practice \\
the learning from other meetings. They will \\
$\begin{array}{l}\text { be asked how to sort numbers, where to start } \\
\text { counting them, how to identify them from their } \\
\text { predecessors and successors. }\end{array}$
\end{tabular}$\quad \begin{aligned} & \text { new that he or she has learned, something that } \\
& \text { has had difficulty, and something he or she likes }\end{aligned}$

Suggestions for adjusting the intervention: Review the idea of stopping over the number, replacing it with the number indication as performed in the session. This task is similar to "what's missing" and "number bingo," so it is important to consider keeping just a few, as it can get very repetitive.

Source: Authors' elaboration (2018).

\section{PILOT STUDY RESULTS}

One can conclude the conduct of the pilot study fulfilled its initial objective. It was possible to put the intervention into practice and to analyze the effectiveness of its proposals, regarding program applicability. The general conclusions will be presented below, and it is important to emphasize the great relevance of this moment of evaluation of the intervention program on counting principles, since the subsequent experimental study, based on this program, depended on data presented here to be better executed.

Regarding the quality of the proposals, it was evident from the records in the researcher's field diary (Charts 1 to 8 ) that most of them worked, but needed 
adaptations. This could be for two reasons: the size of the participants group in the sessions and the prior knowledge brought by them. The initial idea was to work with groups of up to ten children, as was the case of this pilot study, but during the activities we observed this number makes it difficult to perform the intervention: children end up dispersing and it is difficult to maintain attention of all (much time is spent in this process), making the issue of giving more individualized attention to each student problematic, as well as analyzing the evolution of students throughout the meetings. Regarding the children's previous knowledge, it was found that, once engaged in the proposals, they were very quick to complete the tasks, as seen in the researcher's records of "better organizing time”.

Regarding the duration of sessions and activities, the initial idea was 45 minutes, including the movement of students to the intervention site. In the pilot study, the sessions were held in the classroom itself and the ten minutes planned to pick up and bring the children to the meetings were not used. From the 35 minutes dedicated, then, to the realization of each session, the following was observed: contextualization and previous motivation were moments that ended up mixing, becoming a single and brief dialogue of approximately five minutes. Activities occupied the expected time, with few variations, being around 10-15 minutes, and the final systematization did not always have the expected duration, ranging from 5 to 10 minutes. Overall, sessions lasted from 20 to 30 minutes.

Finally, the dynamics thought out for the meetings seemed to work well. Contextualization, followed by prior motivation, was a good way to engage children in discussions, putting into practice the idea of the principles proposed by Clarke et al. (2015) and Fuchs and Fuchs (2001). The activities went well and showed good relationship with the previous moments. Systematization was a more delicate moment, with several registers referring to its reorganization: it was an important point to be rethought for program adjustment (Charts 1 to 8).

\section{REQUIRED ADJUSTMENTS}

After the pilot study and results analysis, adjustments were made to the initially built program, aiming at its better organization to be used in a subsequent experimental intervention study. This, in turn, had a sample of 136 first-grade children and occurred over four months. As a result, the eight sessions, scheduled to be held twice a week over four weeks, were reorganized into four sessions over two weeks. Time limitation was a determining factor in choosing which program tasks would remain and which would be removed. The field diary records assisted in the decisions and adaptations made, resulting in a final intervention program to be used in the experimental study, presented in Chart 9. It should be noted this article will not discuss the effectiveness of the program in the mathematical performance of the participants of the experimental study.

Overall, the dynamics of each session were somewhat mixed: the contextualization and prior motivation became a unique dialogue held at the beginning 


\section{CHART 9}

\section{INTERVENTIONS ON COUNTING PRINCIPLES, AFTER ADJUSTMENTS}

\begin{tabular}{|c|c|c|}
\hline SESSION & $\begin{array}{l}\text { GUIDING QUESTIONS } \\
\text { AND PRINCIPLES }\end{array}$ & PROCEDURES \\
\hline $\begin{array}{l}\text { 1) What are } \\
\text { numbers for? }\end{array}$ & $\begin{array}{l}\text { - Where do we find the } \\
\text { numbers? } \\
\text { - What are they for? } \\
\text { - How can we count } \\
\text { them? } \\
\text { - Is there a right way to } \\
\text { count? } \\
\text { - Which one? } \\
\text { - How to know how many } \\
\text { are there? } \\
\text { - Stable order } \\
\text { - One-to-one } \\
\text { correspondence } \\
\text { - Cardinality }\end{array}$ & $\begin{array}{l}\text { First moment: ask the children the guiding questions. Ask } \\
\text { them to point to the numbers in the intervention room. } \\
\text { Counting room objects without following the stable } \\
\text { order and then following the stable order, but counting } \\
\text { the same item more than once. Ask students if the count } \\
\text { was done correctly. Discuss with the children the answers } \\
\text { to the guiding questions. } \\
\text { Second moment: distribute the stories to the children } \\
\text { and ask what do they have in common. Ask them to tell } \\
\text { which numbers appear on their papers and then propose } \\
\text { to sort them. Then ask the children how many numbers } \\
\text { were counted and how they counted. Explore the idea } \\
\text { that one always counts the same way, in the same order, } \\
\text { and that the last number counted corresponds to the } \\
\text { total number in the set. } \\
\text { Third moment: starting from the idea of constant order } \\
\text { and cardinality, propose to play "which one is missing?". } \\
\text { Arrange a sequence of numbers on the table and ask the } \\
\text { children to observe it for a few minutes. While arranging } \\
\text { the sequence, purposely err the ordering of numbers. } \\
\text { Ask the children to help organize them by pointing out } \\
\text { possible errors. Then ask them to close their eyes and } \\
\text { remove some numbers from the queue, asking them, } \\
\text { after opening their eyes, to indicate which numbers are } \\
\text { missing. At the end of some rounds (each student will } \\
\text { have their turn), have a discussion, asking: how did you } \\
\text { know which numbers were missing? How many numbers } \\
\text { were there? How did you know that? Resume the guiding } \\
\text { questions. }\end{array}$ \\
\hline $\begin{array}{l}\text { 2) How to } \\
\text { count? }\end{array}$ & $\begin{array}{l}\text { - How can we count } \\
\text { without getting lost? } \\
\text { - How do I know if } \\
\text { I already counted a } \\
\text { number? } \\
\text { - How to count a set that } \\
\text { is not organized? } \\
\text { - Stable order } \\
\text { - One-to-one } \\
\text { correspondence } \\
\text { - Order irrelevance } \\
\text { - Cardinality }\end{array}$ & $\begin{array}{l}\text { Resume the previous session, discussing the ideas } \\
\text { already presented and the guiding questions discussed } \\
\text { (we always count the same way and the last number } \\
\text { counted corresponds to the total number of objects } \\
\text { in the set). The researcher should say that sometimes } \\
\text { one gets lost in counting, counting more than once the } \\
\text { same object or forgetting to count another object: when } \\
\text { the set is not in line, it is difficult to count. Question the } \\
\text { children if there are other ways of counting that help us } \\
\text { not to get lost. For this, figures containing balls and some } \\
\text { chips will be used. Initially, ask what the figures have in } \\
\text { common (balls). Then, ask how to find out how many } \\
\text { balls there are in each one (count). Set the example } \\
\text { collectively: count the balls without using the chips, } \\
\text { counting them more than once. Inquire if you counted } \\
\text { correctly. After indications that you did not count right, } \\
\text { ask how to use the tokens to help with counting. Count } \\
\text { again using the tokens to mark the balls already counted. } \\
\text { Then ask if it is always necessary to start with the same } \\
\text { ball. Count starting with another, discussing the value } \\
\text { found. Repeat this movement, starting with another one. } \\
\text { Say that we will always find the same number, regardless } \\
\text { of the ball that will start counting (cardinality). Distribute } \\
\text { three pictures to each and ask students to practice } \\
\text { on their own, one at a time. At the end of the activity, } \\
\text { the ideas presented will be resumed and discussed, } \\
\text { emphasizing the issue of constant order, cardinality, one- } \\
\text { to-one correspondence and order irrelevance. }\end{array}$ \\
\hline
\end{tabular}




\begin{tabular}{|c|c|c|}
\hline SESSION & $\begin{array}{l}\text { GUIDING QUESTIONS } \\
\text { AND PRINCIPLES }\end{array}$ & PROCEDURES \\
\hline 3) Counting & $\begin{array}{l}\text { - What can we count? } \\
\text { - Where do I start to } \\
\text { count? } \\
\text { - Stable order } \\
\text { - one-to-one } \\
\text { correspondence } \\
\text { - Cardinality } \\
\text { - Order irrelevance } \\
\text { - Abstraction }\end{array}$ & $\begin{array}{l}\text { Part One: Resume the previous session by asking the } \\
\text { children to remember what was done and learned. After } \\
\text { a brief discussion on what the students bring, propose to } \\
\text { play two board games, one at a time. The first game will } \\
\text { be "color board". Explain how it works and accompany } \\
\text { the children in the rounds, guiding them. One child at } \\
\text { a time throws the die and must walk to the indicated } \\
\text { color, counting the squares. Then write down, on a small } \\
\text { piece of paper, how many houses they walked. After, it } \\
\text { is another student's turn, and so on until it reaches the } \\
\text { end of the board. After this game, ask how the kids did } \\
\text { to get the color indicated on the dice and if they knew } \\
\text { how many houses they had walked in total. The idea is } \\
\text { that they perceive counting as a useful tool in the game } \\
\text { and indicate paper notes as a way of recording the total } \\
\text { number of houses walked. These discussions will be } \\
\text { permeated by interventions by the researcher, clarifying } \\
\text { that the constant order of counting was followed, that } \\
\text { each house was counted once and only once and that if } \\
\text { we can count colors, we can count anything. } \\
\text { Second part: After the color board game, play "hand } \\
\text { game". Explain and play with the kids. A student throws } \\
\text { the dice and must separate that number of chips, } \\
\text { hand them over to the next classmate, and ask them } \\
\text { to put them on their fingers, indicating which finger to } \\
\text { start with. This will be done by each student, with the } \\
\text { researcher following. In the end, other questions will be } \\
\text { addressed: how do we count this time? Would we need } \\
\text { to have started with the big toe or the little finger, or in } \\
\text { marking the counted fingers there was no problem start } \\
\text { in another order? Does this apply to other things we } \\
\text { count too? If we need to count some objects and they } \\
\text { are messy, how can we do it? Or if someone asks us to } \\
\text { start counting from a certain place, how can we do it? } \\
\text { The focus is to discuss the principle of order irrelevance, } \\
\text { taking what was seen in other sessions. }\end{array}$ \\
\hline $\begin{array}{l}\text { 4) Thinking } \\
\text { about counting }\end{array}$ & $\begin{array}{l}\text { - How can I count in my } \\
\text { head? } \\
\text { - How to organize the } \\
\text { numbers when counting } \\
\text { them? } \\
\text { - How to find a number } \\
\text { without knowing its } \\
\text { name? } \\
\text { - Stable order } \\
\text { - One-to-one } \\
\text { correspondence } \\
\text { - Cardinality } \\
\text { - Order irrelevance } \\
\text { - Abstraction }\end{array}$ & $\begin{array}{l}\text { Resume previous sessions, talk about what has been } \\
\text { seen, done, learned. Discuss guiding questions, resuming } \\
\text { what is the right way to count. Propose a challenge to } \\
\text { see who better learned the numbers: bingo game. Each } \\
\text { student will receive a card and tokens to mark them. } \\
\text { Raffle a card with phrases such as "I am the number } \\
\text { that comes before } 5 \text { and after 3", asking students to } \\
\text { find out what it is. Play until someone does bingo; the } \\
\text { rounds can be repeated. Shortly before the end of the } \\
\text { game, resume the initial ideas and close the intervention } \\
\text { sessions by reviewing what was done at each meeting } \\
\text { and asking three questions: each student should answer } \\
\text { one thing they have learned, one they found difficult and } \\
\text { something they found it easy. }\end{array}$ \\
\hline
\end{tabular}

Source: Authors' elaboration (2018).

\section{LIMITATIONS}

Although there are intervention studies in mathematics, there is a shortage of programs focusing specifically on counting principles, and it was necessary to base the program activities presented on number sense intervention studies in order to adapt them. In addition, not all children participating in the experimental study would perform similarly to the pilot sample, with some possibly showing more difficulties. Finally, because this is a study that must be 
done in a short time and to meet the demands of the school participating in the pilot study, some adaptations had to be done, such as doing it in just two weeks.

\section{CONCLUSIONS}

This work aimed to present the construction of an intervention program on counting principles and its pilot application, aiming to evaluate its applicability for later use in an experimental study. Results of the pilot study indicated the need for adjustments in the intervention program, elucidating the progress of the idealized dynamics, the tasks that could remain in the program, those that needed adaptations and those that could be removed, in order to verify its applicability regarding proposals quality, duration and the children's engagement. Thus, the evaluation of the program made it possible to organize an intervention with better quality and structure.

The study highlighted the need for further research on the creation of intervention programs on counting principles, considering the importance of the theme for the subsequent mathematical development of students and, at the same time, the scarcity of research available in this area.

There is no doubt it is urgent to help teachers to promote pedagogical actions that favor students in the learning process. Therefore, the results of this study can help not only the students, by organizing a specific intervention program in counting principles, but also the teachers, by suggesting practical teaching strategies, low cost and possible to be incorporated into their pedagogical planning. These strategies seek to significantly contemplate the teaching and learning of this area of knowledge, being based on empirical evidence, as the studies discussed throughout this article. In addition, they aim to avoid superficial, repetitive and misunderstanding teaching, as unfortunately still commonly seen in schools. Basing pedagogical planning on research findings, with intention and good strategies, is a key step in favoring not only quality teaching but also meaningful learning for students.

\section{REFERENCES}

ALVES, Fabíola de Souza; BARBOSA, Gabriela dos Santos. Contagem e construção do número por crianças da educação infantil. Perspectivas da Educação Matemática, Campo Grande, v. 9, n. 21, p. 618-638, 2016.

ANTELL, Sue Ellen; KEATING, Daniel P. Perception of numerical invariance in neonates. Child Development, v. 54, n. 3, p. 695-701, 1983.

BARBOSA, Heloiza Helena de Jesus. Sentido de número na infância: uma interconexão dinâmica entre conceitos e procedimentos. Paidéia, Ribeirão Preto, v. 17, n. 37, p. 181-194, 2007.

BERCH, Daniel B. Making sense of number sense: Implications for children with mathematical disabilities. Journal of Learning Disabilities, v. 38, n. 4, p. 333-339, 2005. 
CIRINO, Paul T.; FUCHS, Lynn S.; ELIAS, John T.; POWELL, Sarah R.; SCHUMACHER, Robin F. Cognitive and mathematical profiles for different forms of learning difficulties. Journal of Learning Disabilities, v. 48, n. 2, p. 156-175, 2013.

CLARKE, Ben; DOABLER, Christian; NELSON, Nancy J.; SHANLEY, Caroline. Effective instructional strategies for kindergarten and first-grade students at risk in mathematics. Intervention in School and Clinic, v. 50, n. 5, p. 257-265, 2015 .

CORSO, Luciana V. Aprendizagem e desenvolvimento saudável: contribuições da psicopedagogia. In: SANTOS, Bettina S. S.; ANNA, Lucia de (org.). Espaços psicopedagógicos em diferentes cenários. Porto Alegre: EDIPUCRS, 2013. p. 64-76.

CORSO, Luciana V.; ASSIS, Évelin F. Reflexões acerca da aprendizagem inicial da matemática: contribuições de aspectos externos ao aluno. In: PICCOLI, Luciana; CORSO, Luciana V.; ANDRADE, Sandra dos S.; SPERRHAKE, Renata (org.). Pacto Nacional pela alfabetização na idade certa PNAIC UFRGS: práticas de alfabetização, aprendizagem da matemática e políticas públicas. São Leopoldo: Oikos, 2017. p. 114-138.

CORSO, Luciana V.; DORNELES, Beatriz V. Senso numérico e dificuldades de aprendizagem na matemática. Revista Psicopedagogia, São Paulo, v. 27, n. 83, p. 298-309, 2010.

DEHAENE, Stanislas. Babies who count. In: DEHAENE, Stanislas. The number sense: how the mind creates mathematics. New York: Oxford University Press, 1997. p. 41-66.

DENNIS, Minyi Shih; SHARP, Emily; CHOVANES, Jacquelyn; THOMAS, Amanda; BURNS, Raquel; CUSTER, Beth; PARK, Junkoung. A meta-analysis of empirical research on teaching students with mathematics learning difficulties. Learning Disabilities Research and Practice, v. 31, n. 3, p. 156-168, 2016.

DORNELES, Beatriz Vargas. Princípios de contagem: uma construção progressiva. In: SEMINÁRIO PESQUISA EM EDUCAÇÃO: Região Sul, 5., 2004, Curitiba. Anais [...]. Curitiba: PUCPR, 2004. p. 1-12. CD-ROM.

DOWKER, Ann; SIGLEY, Graham. Target interventions for children with arithmetical difficulties. Understanding number development and difficulties. London: The British Psychological Society, 2010. p. 65-81. (BJEP Monograph Series II, 7).

DYSON, Nancy I.; JORDAN, Nancy C.; GLUTTING, Joseph. A number sense intervention for low-income kindergartners at risk for mathematics difficulties. Journal of Learning Disabilities, v. 46, n. 2, p. 166-181, 2011.

FUCHS, Lynn S.; FUCHS, Douglas. Principles for the prevention and intervention of mathematics difficulties. Learning Disabilities Research \& Practice, v. 16, n. 2, p. 85-95, 2001.

FUCHS, Lynn S.; POWELL, Sarah R.; SEETHALER, Pamela M.; CIRINO, Paul T.; FLETCHER, Jack M.; FUCHS, Douglas; HAMLETT, Carol L. The effects of strategic counting instruction, with and without deliberate practice, on number combination skill among students with mathematics difficulties. Learning Individual Differences, v. 20, n. 2, p. 89-100, 2010.

GIL, Antônio Carlos. Métodos de pesquisa social. São Paulo: Atlas, 2009.

GELMAN, Rochel; GALLISTEL, Charles Randy. The child's understanding of number. Cambridge: Harvard University Press, 1978.

JORDAN, Nancy C.; GLUTTING, Joseph; RAMINENI, Cahitanya. The importance of number sense to mathematics achievement in first and third grades. Learning and Individual Differences, v. 20, n. 2, p. 82-88, 2010.

LOPES, Anemari R. L. V.; ROOS, Liane T. W.; BATHELT, Regina E. O número: compreendendo as primeiras noções. In: BRASIL. Ministério da Educação. Secretaria da Educação Básica. Diretoria de Apoio à Gestão Educacional. Pacto Nacional pela Alfabetização na Idade Certa: quantificações, registros e agrupamentos. Brasília: MEC/SEB, 2014. p. 33-41.

MONONEN, Riikka; AUNIO, Pirjo; KOPONEN, Tuire; ARO, Mikko. A Review of early numeracy interventions for children at risk in mathematics. Early Numeracy Interventions, v. 6, n. 1, p. 25-54, 2014. 
NELSON, Gena; POWELL, Sara. A sytematic review of longitudinal studies of mathematics difficulty. Journal of Learning Disabilites, v. 51, n. 6, p. 523-539, 2018.

NUNES, Terezinha; BRYANT, Peter. Crianças fazendo matemática. Porto Alegre: Artes Médicas, 1997.

PASSOLUNGHI, M. Chiara; VERCELLONI, Barbara; SCHADEE, Hans. The precursors of mathematics learning: Working memory, phonological ability and numerical competence. Cognitive Development, v. 22, n. 2, p. 165-184, 2007.

PRAET, Magda; DESOETE, Annemie. Enhancing young children's arithmetic skills through non-intensive, computerised kindergarten interventions: a randomized controlled study. Teaching and Teacher Education, v. 39, p. 56-65, 2014.

RAMANI, Geetha B.; SIEGLER, Robert S. Promoting broad and stable improvements in low-income children's numerical knowledge through playing number board games. Child Development, v. 79, n. 2 , p. 375-394, 2008.

SPINILLO, Alina Galvão. Usos e funções do número em situações do cotidiano. In: BRASIL. Ministério da Educação. Secretaria da Educação Básica. Diretoria de Apoio à Gestão Educacional. Pacto Nacional pela Alfabetização na Idade Certa: quantificações, registros e agrupamentos. Brasília: MEC/SEB, 2014. p. 20-29.

STARKEY, Prentice; COOPER, Robert G. Perception of number by human infant. Science, v. 210, n. 4473, p. 1033-1035, 1980.

STOCK, Pieter; DESOETE, Annemie; ROEYERS, Herbert. Mastery of the counting principles in toddlers: A crucial step in the development of budding arithmetic abilities? Learning and Individual Differences, v. 19, n. 4, p. 419-422, 2009.

TOLL, Sylke W. M.; VAN LUIT, Johannes E. H. Early numeracy intervention for low-performing kindergartners. Journal of Early Intervention, v. 34, n. 4, p. 243-264, 2013.

NOTA: The first author conducted the empirical work, supervised and guided by the second author, both in the elaboration of the intervention and in the theoretical review and analyses of the article.

\section{HOW TO CITE THIS ARTICLE}

ASSIS, Évelin Fulginiti de; CORSO, Luciana Vellinho. Intervention on counting principles: program development and initial application. Cadernos de Pesquisa, São Paulo, v. 49, n. 174, p. 246-269, Oct./Dec. 2019. https://doi.org/10.1590/198053146560 